\title{
Environmental Management Strategy With a Focus on Sanitary Sewage and Urban Development
}

\author{
Valeria Arenhardt ${ }^{1}$, Flávio de São Pedro Filho ${ }^{2}$, Luciana Rezende Alves de Oliveira ${ }^{3}$, Wellington Cyro de Almeida \\ Leite $^{4}$, Roberto Simplício Guimarães ${ }^{5} \&$ Eduardo Egidio Vicensi Deliza ${ }^{6}$ \\ ${ }^{1}$ Environmental Technology, University of Ribeirão Preto (UNAERP), Brazil \\ ${ }^{2}$ Management and Economics, University of Beira Interior, Covilhã, Portugal. PPGA and PROFIAP / Federal \\ University of Rondônia, Brazil. \\ ${ }^{3}$ Political Science, Federal University of Rio Grande do Sul (UFRGS), Brazil \\ ${ }^{4}$ Civil Engineering - Hydraulics and Sanitation, University of São Paulo (EESC-USP), Brazil \\ ${ }^{5}$ Nuclear Energy, Nuclear and Energy Research Institute (IPEN), University of São Paulo (USP), Brazil \\ ${ }^{6}$ Regional Development and Environment (PGDRA/UFRO), Federal University of Technology, Brazil \\ Correspondence: Valeria Arenhardt, Environmental Technology, University of Ribeirão Preto (UNAERP), Brazil.
}

Received: August 21, 2020

doi:10.5430/ijba.v11n6p109
Accepted: October 7, 2020

Online Published: November 29, 2020

URL: https://doi.org/10.5430/ijba.v11n6p109

\begin{abstract}
The Amazon boasts a great environmental heritage and abundance of water resources, it is in this remarkable biome where the worst rates of access to basic sanitation services and public health indicators are. This research aims to use the SWOT analysis to generate knowledge capable of subsidizing the public manager in the elaboration of strategic planning to implement sanitary sewage according to the National Policy for Basic Sanitation in a municipality of the Brazilian Amazon under development and urban expansion. The practices adopted for this task relate to the concepts of the SWOT matrix, public policies for basic sanitation with a focus on sanitation, urban sprawl and social impacts on human health related to poor sanitation. Identifying in the municipal legal norms the strategic planning to order the development and the urban expansion and the practices foreseen to meet the National Policy for the Basic Sanitation and implantation of the sanitary sewage in the studied municipality. This is a descriptive exploratory research based on document and field research according to legal and environmental norms with qualitative and quantitative results. Despite the result demonstrating that the strategic planning for the implementation of sewage in urban expansion projects results in sustainable urban development, the municipality under study did not meet the legal and environmental standards for the implementation of sewage in new subdivisions causing environmental, social and economic problems.
\end{abstract}

Keywords: SWOT analysis, basic sanitation, strategic planning

\section{Introduction}

The lack of adequate basic sanitation is considered one of the main causes of pollution and contamination of water for human supply, contributing to cases of waterborne diseases. The National Water Agency (NWA) informs that Brazil has about $12 \%$ of the planet's freshwater, $80 \%$ of which is in the Amazon.

The National Sanitation Information System (NSIS) shows that in 2015 around 83.3\% of the Brazilian population had access to treated water and that more than 34 million Brazilians did not have this service, considered essential for the maintenance of public health. Regarding sewage collection, in 2015 only $50.3 \%$ of the population received this service, which means that more than 102 million Brazilians did not have access to the sewage service. The situation becomes even more worrying in relation to treated sewage, which according to 2016 data, only $42.7 \%$ of the total sewage collected receives minimal treatment before returning to the water sources. According to the 2010 data, it is possible to observe that in the north and northeast regions, basic sanitation services are very precarious or in disagreement with legal and environmental standards. (Ministry of Cities, Brazil, 2016).

According to data from the Informatics Department of the Unified Health System (IDUHS) in 2013, hospitalizations of patients with diseases, caused by the lack of basic sanitation, such as infectious gastroenteritis and complications had 
an average of 37.17 inhabitants in the north region and 35.44 in the northeast region, considering the number of cases per 10,000 inhabitants. This representation was the largest compared to the other regions of the country and higher than the national average, which was 19.94 inhabitants for every 10,000 inhabitants.

In order to comply with legal and environmental standards, it is necessary to systematize actions for strategic planning covering the environmental, social and economic aspects, associated with the migration process and urban development and expansion. The municipal public power should raise reflections for an interdisciplinary approach, which allows the management of water resources, the implementation of basic sanitation with the adhesion of the inhabitants, aiming at the promotion of public health in search of the well-being of current and future generations.

To elicit reflections about the implementation of basic sanitation, focusing on sanitary sewage, this descriptive exploratory research is based on bibliographic studies and field research, in search of qualitative and quantitative data that can answer the question: Is strategic planning through SWOT analysis able to trigger actions to implement sanitation in a city in full development and urban expansion? The choice of the sample was directed to the municipal managers, involved with the projects of development and urban expansion and implementation of basic sanitation in the municipality under study. The problem encountered is that the municipality authorizes new subdivisions without requiring the implementation of sanitary sewage and, therefore, promoting urban expansion that does not meet the legal norms and sustainable urban development

\section{Goals}

The goal of this research is to use the SWOT matrix to generate information capable of subsidizing the public manager, in the elaboration of the strategic planning, to implement the sanitary sewage according to the National Policy for Basic Sanitation, in a municipality in the Brazilian Amazon in urban development and expansion. The specific goals are associated with the characterization and conceptualization of the SWOT matrix, public policies for basic sanitation with a focus on sanitation and urban expansion and the social impacts on human health related to the lack of basic sanitation (1); Identifying in the municipal legal norms the strategic planning to order the development and urban expansion and the practices foreseen to meet the National Policy for Basic Sanitation for the implementation of sanitary sewage in the municipality under study (2); Propose sustainable strategic planning based on the SWOT matrix to implement sanitary sewage in the city in full urban expansion. (3). The SWOT analysis was used to identify and assess internal strengths and weaknesses, opportunities and external threats to associate with basic sanitation in a city in full urban expansion, to propose strategic planning to implement sanitation in the municipality under study. This research is of interest to municipal managers and those who develop socio-environmental and economic studies related to basic sanitation.

\section{Theoretical and Conceptual Review}

According to Brazilian legal norms, the municipality is the holder of planning activities as a means of universalizing public basic sanitation services that are guided by public policies to promote sustainable development through social participation.

Law No. 11,445 of January 5, 2007 establishes national guidelines for basic sanitation to improve the quality of life and well-being of the Brazilian population. It prescribes that sanitation is the set of services, infrastructures and operational facilities that include drinking water supply, sanitary sewage, urban cleaning and solid waste management, drainage and rainwater management, as well as cleaning and preventive inspection of urban networks to promote a sustainable environment. The fundamental principles establish the need to articulate basic sanitation with the policy of urban and regional development, housing, poverty eradication, environmental protection and health promotion, as determining factors to improve the population's quality of life.

The Federal Constitution of Brazil gives the municipal public authority the competence and responsibility to order urban development and makes it mandatory to prepare the master plan, for cities with more than twenty thousand inhabitants, as a basic instrument of urban development and expansion policy. It consists of strategic planning for sustainable development. However, Federal Law No. 10,257, of July 10, 2001 establishes general guidelines for urban development policies and among the goals it highlights the population's right to basic sanitation for the promotion of health and the sustainable development of cities.

According to Ribeiro and Rooke (2010) the World Health Organization (WHO) conceptualizes Basic Sanitation as the control of all factors of the physical environment that exercise or may have a deleterious effect on the living beings of the planet and that must be sustained in the management of a set of actions that can preserve the conditions of the environment to prevent diseases and promote health, improve the population's quality of life and individual productivity. The same authors affirm that sanitary sewage is part of the set of activities related to basic sanitation that are associated with actions to prevent pollution of water sources such as rivers and seas and that actions are needed to ensure that the water consumed by the population is of quality to prevent diseases arising. 
When studying the implications of territorial planning, Pereira (2009) emphasizes the capacity of the master plan to contribute to the construction of policies and agendas for the implementation of basic sanitation in Brazil and, therefore, health promotion and healthy and sustainable environmental development. Santana, et al. (2012) argue that the lack of access to treated water and the collection and treatment of sewage can cause innumerable social losses, related to health because they negatively influence the well-being and quality of life of an entire society, also leading to environmental degradation. And yet in this direction Nunes (2015) states that basic sanitation is associated with public health issues, that its absence or inefficiency limits access to drinking water, which is an essential asset to human life, thus contributing to various pathologies spread with great ease.

According to Moyses Filho (2010), the SWOT matrix is an assessment tool and is part of the School of Design, which in the 1960s proposed a model to identify an organization's internal capacity and external environment. It is a tool that provides information to support strategic planning with the definition of goals and guidelines that are in accordance with the reality of the problem studied. The SWOT analysis for Chiavenato (2009) is a management tool capable of representing situational reality indicators, by identifying the internal strengths and weaknesses, the external opportunities and threats of an environment, and then proposing strategic planning for appropriate actions. He highlights that the SWOT Analysis is an original acronym for four words in the English language: Strength, Weakness, Opportunities and Threats

\section{Materials and Methods}

This research was conducted in a municipality in the Brazilian Amazon region where data from the Brazilian Institute of Geography and Statistics (BIGS) in the Census (2018) indicate that the population grew around $46 \%$ between the years 2007 and 2018 and has an estimated population of 97,448 inhabitants. Basic sanitation was not implemented in the municipality and the source of water supply is the Parecis Aquifer. There is no sewage system and no sewage treatment plant.

The study assumes an exploratory-descriptive character according to Gil (2017) and Marconi and Lakatos (2011) because it allows us to understand the reality of a place and, through bibliographic studies, propose sustainable planning aimed at the implementation of sanitary sewage in a region of the Brazilian Amazon.

Based on Gil's studies (2017), field research was chosen to deepen the knowledge on the topic and through the questionnaire of interviews with public agents, responsible for the master plan and authorization of urban expansion projects and with those responsible for the municipal basic sanitation plan, to identify the sewage actions carried out between the years 2007 to 2018. Data collection took place in the months of September and October of 2018. For the research, the public agents directly involved with the planning for urban development and expansion in the municipality project were selected.

The SWOT analysis was used to represent internal strengths and weaknesses, opportunities and external threats in the implementation of sanitary sewage in a municipality in full urban expansion. With the results, strategic planning for the implementation of sanitary sewage and promoting sustainable urban development was proposed.

The centre of this research lies initially on the identification of the problem, definition of goals, types of research to meet the proposed goals, as well as the search for information on basic sanitation and urban expansion in the studied municipality and proposing strategic planning for actions and implementation of sanitary sewage.

The technical procedures adopted reach the understanding of aspects that society outlines in the structural reality.



Figure 1. Procedures adopted in the research 
Figure 1 represents the flowchart of the procedures adopted to incorporate into the results the main knowledge acquired and the relationship established between government actions and strategic planning based on the SWOT analysis to implement sanitation in a municipality in full expansion in the northern region of Brazil and, therefore, promoting sustainable urban development.

\section{Results}

Based on the Municipal Basic Sanitation Plan (2014), there is no sewage collection and treatment station in the municipality, the current system is individual and in most cases, it is precarious and without any type of treatment and $90 \%$ of households use rudimentary cesspools and the other $10 \%$ use septic tanks. The Municipal plan points out that the implementation of the sanitary sewage treatment system is foreseen for the period from 2014 to 2034. It is worth mentioning that this forecast includes allotments authorized after Law 11,445 of 2007, which establishes national guidelines for basic sanitation. However, Municipal Decree No. 19,236 of 2009 and Complementary Law No. 171 of 2011 provide that the installation of basic infrastructure, including sanitary sewage for new subdivisions, will be on behalf of the owner of the project, which did not occur.

After the approval of Law no 11,445 of January 2007, until the date of this research, September 2018, the municipal government authorized for private individuals the subdivisions and condominiums indicated in Table 1, the actions associated with the development and urban expansion are represented.

Table 1. Urban expansion with and without plumbing for sewage in the period of 2007-2018

\begin{tabular}{lllllll}
\hline Year/Population & \multicolumn{6}{l}{ Allotments authorized by the Municipality in the period 2007 to 2018 } \\
\hline $\begin{array}{l}2007 \\
66.756 \text { hab. }\end{array}$ & Units & $\begin{array}{l}\text { Number } \\
\text { authorized } \\
\text { subdivisions and } \\
\text { condominiums }\end{array}$ & $\begin{array}{l}\text { Number } \\
\text { plots } \\
\text { authorized } \\
\text { segment }\end{array}$ & $\begin{array}{l}\text { of } \\
\text { per }\end{array}$ & $\begin{array}{l}\text { Allotments with } \\
\text { appropriate } \\
\text { plumbing } \\
\text { sewage }\end{array}$ & $\begin{array}{l}\text { Allotments } \\
\text { without } \\
\text { for } \\
\text { plumbing } \\
\text { sewage }\end{array}$ \\
\hline $\begin{array}{l}\text { 2018 } \\
97.448 \text { hab. }\end{array}$ & Allotments & 42 & 17.966 & 2.077 & 15.889 \\
\cline { 2 - 7 } & Condominium & 08 & 901 & 636 & 265 \\
\cline { 2 - 7 } & Total & 50 & 18.867 & 2.713 & 16.154 \\
\hline
\end{tabular}

18,867 plots were put up for sale, however, only 2,713 with plumbing for sewage, according to a project registered in the city hall. Despite the Brazilian legal norms, specific decrees of the executive branch were identified exempting the owners of new subdivisions from the obligation to install the sewage network.

Of the authorizations carried out by the municipal government, $14.38 \%$ is channelled for sewage installation. It is imperative to remember that selective waste collection has not been implemented and there is no sanitary sewage treatment station in the municipality. Despite the shared responsibility, the 1988 Federal Constitution of Brazil prescribes that it is the responsibility of the municipal public power to provide for the design and installation of Sewage Treatment Stations (STS) and yet elects municipalities to promote strategic planning for urban development and expansion and the master plan is the basic instrument to define the respective policies that will be adopted by the municipalities.

The Master Plan of the studied municipality presents the goals for basic sanitation and establishes the implementation of sewage collection and treatment networks and in the guidelines for the sanitation service establishes a program for the implementation of an alternative sewage collection, removal and treatment system and mentions the need to establish goals for the implementation of the sewage collection network. The topic of basic sanitation is timidly approached because it does not foresee actions to implement sanitary sewage and the practices are not associated with what is prescribed by the municipality.

From 2007's Federal Law No. 11,445, which establishes national guidelines for basic sanitation and regulates the implementation of sanitary sewage until 2018 , the date of this survey, there was an increase of 30,702 inhabitants, with the previously existing population of 66,746 inhabitants, totalling 97,448 inhabitants in 2018. These inhabitants do not have sanitary sewage, however, according to the National Water Agency (NWA), the region under study is part of the Amazon biome that holds $80 \%$ of Brazil's freshwater source. 


\section{Discussion}

It is evident that 11 years after the approval of Law number 11,445 of 2007, which establishes national guidelines for basic sanitation and 12 years after the approval of the Master Plan for the municipality, sanitary sewage was not implemented to meet the determinations of national legal norms and enforcement predicted by the municipality itself. Therefore, this strategic planning is justified to subsidize public managers, with information, to promote sustainable urban development and expansion in a city in the Brazilian Amazon.

According to the Municipal Basic Sanitation Plan, there is a forecast to invest an estimated amount of $\mathrm{R} \$ 92.787 .800,19$ in the implementation of sanitary sewage to serve only $60 \%$ of households. These data served as a basis for the projection of savings in financial resources, if, since 2007, when the subdivisions were released, municipal managers in the use of the prerogatives complied with the legal rules.

The importance of strategic planning to implement sanitary sewage in developing cities is represented in the financial analysis in Table 2 that shows the capacity to consolidate efficient and effective actions that can generate savings for the municipality under study.

Table 2. Municipal savings in the implementation of the sewage network in new subdivisions

\begin{tabular}{|c|c|c|c|c|}
\hline Year of 2007 & $\begin{array}{l}\text { from } 01 / 2007 \text { to } \\
12 / 2013\end{array}$ & 2013 & $\begin{array}{l}\text { from } 01 / 2014 \text { to } \\
10 / 2018\end{array}$ & 2018 \\
\hline $\begin{array}{l}\text { Number } r \text { of } \\
\text { households in the } \\
\text { municipality of } \\
\text { Vilhena (Synopsis } \\
\text { IBGE, 2007) }\end{array}$ & $\begin{array}{l}\text { Number of } \\
\text { allotments } \\
\text { authorized by the } \\
\text { Municipality } \\
\text { (Source: Vilhena } \\
\text { City Hall website, } \\
\text { 2018) }\end{array}$ & $\begin{array}{l}\text { House project in the } \\
\text { municipality in } \\
2013 \text {, considering } \\
\text { only authorized } \\
\text { subdivisions }\end{array}$ & $\begin{array}{l}\text { Number of allotments } \\
\text { authorized by the } \\
\text { Municipality. }\end{array}$ & $\begin{array}{l}\text { Total households } \\
\text { that require basic } \\
\text { sanitation }\end{array}$ \\
\hline 21.326 & 3.070 & 24.396 & 15.797 & 40.193 \\
\hline $\begin{array}{l}\text { Calculation of the } n \\
\text { for the implementati } \\
\text { to relate to resources } \\
\text { households and incre } \\
\text { households from } 201\end{array}$ & $\begin{array}{l}\text { umber of households } \\
\text { on of basic sanitation } \\
\text { to serve } 60 \% \text { of the } \\
\text { ase in the number of } \\
4 \text { to } 2018 \text {. }\end{array}$ & $\begin{array}{l}14.638 \text { Corresponds } \\
\text { to } 60 \% \text { of total } \\
\text { households in } 2013\end{array}$ & $\begin{array}{l}64.75 \% \text { growth in the } \\
\text { number of households } \\
\text { Period 2013/2018 }\end{array}$ & $\begin{array}{l}40.193 \\
\text { Corresponds to } \\
100 \% \\
\text { households } \\
\text { projected for } 2018\end{array}$ \\
\hline $\begin{array}{l}\text { Investment projection } \\
\text { serve } 60 \% \text { of housel } \\
\text { growth in the numbe } \\
2013 \text { to } 2018 \text {. }\end{array}$ & $\begin{array}{l}\text { sanitary sewage to } \\
\text { Ids considering the } \\
\text { of households from }\end{array}$ & $\begin{array}{l}\text { R \$ 92.787.800,19 } \\
\text { Investment } \\
\text { projection in } 2013 \\
\text { in sanitary sewage } \\
\text { for } 60 \% \text { of } \\
\text { households }\end{array}$ & \multicolumn{2}{|c|}{$\begin{array}{l}\mathrm{R} \$ 254.776 .612,45 \\
\text { Projection of investment in } 2018 \text { in sanitary } \\
\text { sewage for } 100 \% \text { of households. } \\
(\mathrm{R} \$ 92.787 .800,19 / 14.638 \times 40.193)\end{array}$} \\
\hline \multicolumn{2}{|c|}{$\begin{array}{l}\text { Economic projection for the municipality if } \\
\text { public managers complied with legal } \\
\text { norms and demanded the implementation } \\
\text { of sanitary sewage in new subdivisions } \\
\text { sold by private companies. }\end{array}$} & $\begin{array}{l}\text { Total of } 16,154 \\
\text { households released } \\
\text { for sale without } \\
\text { plumbing for } \\
\text { sanitary sewage. }\end{array}$ & \multicolumn{2}{|c|}{$\begin{array}{l}\text { Projection of the average saving for the } \\
\text { municipalities with the strategic planning } \\
\text { in the implantation of sanitary sewage in } \\
\text { the municipality. } \\
\mathrm{R} \$ 102.397 .467,16\end{array}$} \\
\hline
\end{tabular}

The result represents a saving for the municipality of approximately $\mathrm{R} \$ 102.397 .467,16$ if the law that defines guidelines for implementing basic sanitation were regulated and applied by the municipality. However, here we are not quantifying and qualifying the environmental and social problems resulting from the lack of strategic planning for the implementation of basic sanitation in a city in the northern region of Brazil.

This scenario points to inefficiencies in complying with legal and environmental standards and the need for sustainable strategic planning to implement sanitation in the region. Strategic planning systematizes temporal actions, capable of directing activities to meet the requirements of legal and environmental standards. 
Table 3. SWOT analysis to implement sanitary sewage through strategic planning

\begin{tabular}{l} 
Positive \\
\hline Strengths (S) \\
\hline -There are national legal and environmental \\
standards that regulate and systematize the \\
implementation of basic sanitation in all Brazilian \\
municipalities. \\
-The Brazilian Magna Carta attributes to the \\
municipality the responsibility for implementing \\
basic sanitation, giving prerogatives to demand \\
compliance with the federal legal norm. \\
-The municipality has regulated federal rules with a \\
forecast to implement sanitary sewage in the city. \\
-The municipality under study has a Master Plan for \\
the year 2006 and mentions the importance of \\
sewage for human health. \\
Opportunities (O) \\
-Update the Master Plan with a specific chapter for \\
basic sanitation, with specific goals. \\
-Rely on specialized people with a multidisciplinary \\
team to systematize actions and carry out projects \\
and the implementation of basic sanitation \\
throughout the municipality. \\
- Approve in the legal norms the formation of work \\
teams with effective employees of the municipality \\
with specialized people to follow the actions with the \\
changes of managers.
\end{tabular}

External - Enforcing the municipal legal norms and actions to implement basic sanitation.

-Systematize clear rules to give the developers of new subdivisions the responsibility for basic infrastructure, highlighting sanitary sewage as a sine qua non condition to allow allotment sales.

-Establish dialogue with projects that have already Negative

Weaknesses (W)

- There was no perceived inspection to enforce national legal and environmental standards for the effective implementation of basic sanitation.

- There are municipal legal rules, but no actions have been identified to start the implementation of sanitary sewage in the municipality.

-It was identified that there is no sequence of actions with the change of municipal managers.

-The Master Plan is from 2006 and is outdated. It is a strategic planning document for urban development and expansion and the implementation of sanitary sewage.

\section{Threats (T)}

- Compromising of existing natural resources in an important region of the Brazilian Amazon.

-With the current pit system, there is an imminent threat of contamination of freshwater from springs and groundwater.

-The threat of contamination of $80 \%$ of the freshwater source in Brazil located in the Brazilian Amazon.

-Water contamination increases the number of people with health problems, which generates costs for the municipality's health sector.

-The municipality assumes the costs for the implementation of sanitary sewage while the developers of subdivision gain from the sale of the land, generating a burden for a municipality that is in economic, social and environmental difficulties. been released and that have not complied with the legal rules foreseen in the projects and the effective implementation of sanitary sewage to ensure compliance with the legal standard

-After technical studies, plan organize and build ETE Sewage Treatment Stations in the municipality.

On the first chart, it is possible to identify the internal and external strengths and weaknesses, as well as the external opportunities and threats found to implement sanitation in the municipality under study. Based on this analysis, strategies were proposed to maximize strengths and opportunities, minimizing the weaknesses and threats encountered.

The SWOT Analysis is an instrument to promote strategic planning and propose a new posture for managers, in the face of environmental, economic and social problems arising from the lack of sanitation in the studied municipality. It is worth highlighting important actions for the municipality to make strategic planning viable: 
1. Promote studies to update the Master Plan based on Federal Law No. 10,257 of 2001, the City's Statute which establishes general guidelines for urban development policies, Federal Law No. 11,445 of 2007 that establishes general guidelines for basic sanitation and the laws, regulations and legal and environmental standards related to basic sanitation and urban development and expansion.

2. Establish a multidisciplinary team, perennial and with knowledge about the region considering the diversity, for technical-scientific studies of regional characteristics such as soil, climate, relief, population, production and consumption system for the elaboration of projects to implement basic sanitation in a municipality planning to implement sanitary sewage.

3. To seek federal resources through projects to propose actions and install sanitary sewage, with adequate and modern constructions of sewage treatment plants in the municipality.

4. In allotments implemented from 2007 to 2018, enforce federal and municipal legal norms through negotiations with entrepreneurs, so that they install the plumbing for sanitary sewage in the lots that are for sale.

5. Involving segments of the community to identify problems and establish sustainable economic, social and environmental planning without errors that may lead to future problems.

6. In projects and plans, clearly define goals and responsibilities and make them public, as well as involving sectoral agreements so that the community also feels responsible and can supervise actions.

7. Involving the community through environmental education, explaining to the population the importance of basic sanitation and the social, economic and environmental benefits for the promotion of the well-being of current and future generations.

Finally, strategic planning can contribute to consolidate actions aimed at sustainable urban development and expansion, avoiding environmental, economic and social problems for current and future generations.

\section{Conclusions}

There are countless environmental problems generated by the lack of sewage. The main ones are those associated with the pollution of waters in rivers and seas that generate health problems and interfere with the quality of life on the planet.

The result answers the research question, strategic planning is capable of developing actions to implement sanitation in a city in full development and urban expansion, as well as in all cities that have problems related to basic sanitation. After analyzing the results of the research, it was concluded that one of the main actions is to demand from companies that own new subdivisions the implementation of the basic infrastructure as seen in the legal norms. According to legal norms sewage is a part of the basic infrastructure. This requirement is possible because it is legally foreseen, therefore, reducing the financial disbursement of the municipality, with the implementation of sewage in new ventures, which generate financial resources for themselves from the sale of terrains to the population.

The result of the research points out that in the municipality, actions foreseen in the legal rules of basic sanitation were not implemented. However, this non-compliance is reflected in serious social, environmental and economic problems, considering the release of subdivisions without the necessary basic infrastructure, such as sanitation, failing to promote sustainable urban development and generating burdens for the federated entities.

Finally, municipal strategic planning is important for sustainable urban development and expansion. The result is of interest to municipal managers, urban allotment companies that aim at sustainable expansion and development, and to those who are committed to studying strategic planning for sustainable development.

\section{References}

Brazil, Informatics Department of the Unified Health System (DUHS). (2013). Indicators of morbidity. Retrieved from http://tabnet2.datasus.gov.br/cgi/deftohtm.exe?idb2013/d32.def

Brazil, National Congress. (1988). Constitution of the Federative Republic of Brazil. Highland. Retrieved from http://www.planalto.gov.br/ccivil_03/Constituicao/Constituicao.htm

Brazil, National Sanitation Information System (NSIS). (2016). Diagnosis of Water and Sewage Services - 2016. Retrieved from http://etes-sustentaveis.org/wp-content/uploads/2018/03/Diagnostico_AE2016.pdf

Brazil, National Water Agency (ANA). (2018). Quantity of water - 2018. Retrieved from http://www3.ana.gov.br/portal/ANA/panorama-das-aguas/quantidade-da-agua 
Brazil, Presidency of the Republic Casa Civil. (2007). Federal Law No. 11,445, of January 5th, 2007. Establishes national guidelines for basic sanitation. Retrieved from http://www.planalto.gov.br/ccivil_03/_ato2007-2010/2007/lei/111445.htm

Brazil, Presidency of the Republic Civil House. (2001). Federal Law No. 10,257, of July 10th, 2001. Regulates the Arts. 182 and 183 of the Federal Constitution. Establishes general guidelines for urban policy and takes other measures. Retrieved from http://www.planalto.gov.br/ccivil_03/LEIS/LEIS_2001/L10257.htm

Brazil, Presidency of the Republic Civil House. (2010). Federal Decree No. 7,217, of June 21st, 2010. Regulates Law No. 11,445, of January 5th, 2007. Establishes national guidelines for basic sanitation. Retrieved from http://www.planalto.gov.br/ccivil_03/_ato2007-2010/2010/decreto/D7217.htm

Brazil, Presidency of the Republic, Ministry of Cities. (2015). Diagnosis of Water and Sewage Services. Retrieved from http://www.snis.gov.br/diagnostico-agua-e-esgotos/diagnostico-ae-2015

Chiavenato, I. (2009). Administration in the new times (2nd ed.). Elsevier, Rio de Janeiro.

Gil, A. C. (2017). How to design research projects (6th ed.). Atlas, São Paulo.

IBGE, Brazilian Institute of Geography and Statistics. (2018). Counting the Population in 2007. Households. Retrieved from https://ww2.ibge.gov.br/home/estatistica/populacao/contagem2007/contagem.pdf

IBGE, Brazilian Institute of Geography and Statistics. (2018). Demographic Census: Cities 2018. Retrieved from http://cidades.ibge.gov.br/xtras/perfil.php?lang=\&codmun=110030

Marconi, M. de A., \& Lakatos, E. M. (2011). Scientific methodology (6th ed.). Atlas, São Paulo.

Moysés, F. J., Kestelman, H. N., Becker, Jr. L. C., \& Torres, M. C. S. (2010). Strategic Planning and Management in Health Organizations. FGV, Rio de Janeiro.

Nunes, V. R. de S. (2015). The basic sanitation sector in Brazil: Challenges and perspectives, Monograph. Production Engineering Course. Federal University of Rio de Janeiro - UFRJ. Retrieved from http://monografias.poli.ufrj.br/monografias/monopoli10014809.pdf

Pereira, R. R. (2009). Territorial Planning: Its Implications for Health Promotion and Environmental Justice. Space and Time, (26), 19-27.

Ribeiro, J., \& Werneck, R. J. M. S. (2010). Basic sanitation and its relationship with the environment and public health. Course Conclusion Paper, Specialization in Environmental Analysis, Federal University of Juiz de Fora, Juiz de Fora. Retrieved from http://www.ufjf.br/analiseambiental/files/2009/11/TCC-SaneamentoeSa\%C3\%BAde.pdf

Santana, A. T., Luvizotto, C. K., \& Cuba, R. M. F. (2012). Basic sanitation and its relationship with quality of life in settlements in the municipality of Teodoro Sampaio - SP, Rev. VIII Alta Paulista Environmental Forum, 8(12), 48-62.

Retrieved

from http://amigosdanatureza.org.br/publicacoes/index.php/forum_ambiental/article/view/354/361

Vilhena, City Hall. (2006). Municipal Law No. 2,065 of 2006. Establishes the Participative Master Plan and provides for the system and process for planning and managing urban development in the municipality of Vilhena.

Vilhena, City Hall. (2009). Municipal Decree 19.236 of 2009. Regulates the approval of subdivisions in the municipality of Vilhena and takes other measures.

Vilhena, City Hall. (2011). Municipal Complementary Law No. 171/2011, of 11/03/2011.

Vilhena, City Hall. (2013). Municipal Law No. 3,799 of December 10, 2013 and Law No. 3895 of May 20, 2014. Municipal Basic Sanitation Plan for the Municipality of Vilhena (PLAMSABAV).

\section{Copyrights}

Copyright for this article is retained by the author(s), with first publication rights granted to the journal.

This is an open-access article distributed under the terms and conditions of the Creative Commons Attribution license (http://creativecommons.org/licenses/by/4.0/). 